\title{
EFEKTIVITAS MODEL PELATIHAN APRESIASI SENI TARI SEMARANGAN
}

\author{
Amanda Chendramelistiana*Wahyu Lestari \\ Alumni mahasiswa Jurusan Sendratasik, Fakultas Bahasa dan Seni \\ Universitas Negeri Semarang \\ Amandachendra31@gmail.com*Wahyu_pyarlestari@yahoo.co.id
}

\begin{abstract}
Abstrak
Model pelatihan apresiasi tari Semarangan telah diuji faliditas dan reabilitasnya dan dinyatakan efektif digunakan. Tari Semarangan diteliti karena memiliki gerakan dan iringan musik yang dinamis, sesuai dengan karakter siswa kelas 6 Sekolah Dasar, sehingga siswa lebih mudah mengikuti. Penelitian bertujuan: (1) menghasilkan modul dan video pembelajaran tari Semarangan untuk siswa Sekolah Dasar kelas 6 pada mata pelajaran SBK (Seni Budaya dan Ketrampilan) yang valid dan reabel. Metode kuantitatif digunakan untuk menguji validitas, reabilitas dan keefektivan modul sehingga, modul dapat digunakan. Hasil penelitian menunjukan bahwa model pelatihan apresiasi seni tari Semarangan menggunakan modul pembelajaran dan dilengkapi dengan video tari Semarangan dinyatakan sangat efektif digunakan, dapat dilihat dari meningkatnya hasil belajar kognitif siswa sebesar 43,08, keefektifan penerapan modul 3,19 (tinggi) dan 65\% dari jumlah siswa menyukai pelajaran seni tari. Kesimpulan menunjukan bahwa modul pembelajaran tari Semarangan efektif dapat digunakan. Saran bagi guru modul pembelajaran tari Semarangan digunakan sebagai acuan dalam pembelajaran.
\end{abstract}

Kata kunci: Model pelatihan, apresiasi, tari Semarangan, efektivitas

\section{A. PENDAHULUAN}

Pendidikan seni khususnya pada seni tari sebagai materi pembelajaran yang diberikan kepada anak sejak usia dini agar anak memiliki kemampuan dan ketrampilan dalam tari. Bentuk kegiatannya berupa aktivitas fisik (gerak) dan dapat merasakan keindahan, yang bertuang dalam kegiatan berekspresi, bereksplorasi, berkreasi, dan berpartisipasi melalui tari. Dari kegiatan tersebut akan 
diperoleh ketrampilan, pengalaman menari dan merasakan sentuhan keindahan dalam tari (Hartono 2011: 62-63). Pendidikan seni ialah kegiatan pemberian pengalaman estetik (aesthetic experience) kepada siswa. Pemberian pengalaman estetik diberikan melalui dua kegiatan yang saling berkaitan, yakni apresiasi (aprecition) dan kreasi (creation). Pada kegiatan apresiasi dan kreasi (Included) terkandung nilai ekspresi sebagai bentuk ungkapan yang bermakna. Melalui pengalaman estetik, siswa diharapkan dapat menginternalisasikan (meresapi atau mengakarkan) nilai-nilai estetik yang berfungsi untuk melatih kepekaan rasa, kecerdasan intelektual, dan mengembangkan imajinasinya (Jazuli 2008: 37).

Salah satu usaha yang dapat dilakukan agar potensi budaya atau tari daerah dapat berkembang yaitu mengajarkan, menamamkan atau melestarikan tari daerah tersebut semenjak anak usia dini (pada anak Sekolah Dasar) agar mengetahui tarian yang ada pada daerah tersebut. Adanya pembelajaran seni tari pada tingkat Sekolah Dasar (SD) agar siswa mengatahui dan memahami kesenian yang ada pada kota mereka, berapresiasi dan kreatifitas, melatih keluwesan bergerak, pembentukan badan dan berkreasi. Pelajaran seni tari juga dapat mengurangi kejenuhan siswa dalam belajar mengajar dikelas. Selama proses pemberian materi, siswa diarahkan untuk mendapatkan pengalaman apresiasi sekaligus rekreasi melalui gerakan-gerakan tari sehingga dapat menimbulkan minat siswa pada mata pelajaran seni tari. Karena dalam proses belajar menari yang mengutamakan ketrampilan motorik dimana pada ketrampilan belajar menari menggerakan anggota tubuh. Perkembangan motorik dapat dirangsang dengan gerak dan musik (Hartono 2012: 30).

Pembelajaran seni tari sangat bergantung pada guru dalam pengelolaan kelas dan pemberian motivasi kepada peserta didik. Pada proses pembelajaran, guru membutuhkan pedoman untuk proses 
pengajaran yang disebut dengan

kurikulum.

Menurut Mida Latifatul (2013:15) Kurikulum ialah sejumlah rencana isi yang merupakan sejumlah tahapan belajar yang didesain untuk siswa dengan petunjuk intituisi pendidikan yang isinya berupa proses yang statis ataupun dinamis dan kompetensi yang harus dimiliki.

Pelatihan yang berasal dari kata latihan (training) merupakan proses kerja atau berlatih yang sistematis dan dilakukan dalam waktu yang lama dan secara berulang-ulang dengan beban latihan yang semakin meningkat untuk mencapai suatu tujuan yang telah ditetapkan (Joko, 2010: 21).

Apresisasi merupakan suatu kegiatan yang didasari oleh penghayatan,pemahaman dan penilaian suatu dalam perwujudan gerak.

Tari Semarangan adalah bentuk tarian yang dapat ditarikan secara tunggal, berpasangan atau kelompok yang dilatar belakangi oleh unsur keprihatinan keadaan masyarakat seni di kota Semarang, bahwa pada tahun 1990-an belum memiliki seni khas Semarang. Hingga akhirnya Al.Agus Supriyanto menciptakan tari Semarangan dan bekerja sama dengan Grup Musik Gambang Semarang A.S.R asuhan bapak Iman Prakosa mencoba menyusun salah satu tari. Kekuatan tari Semarangan terletak pada dinamika gerak, irama gerakan dan musik iringan tari tersebut. Bentuk sajian tari Semarangan dapat ditarikan secara tunggal, berpasangan ataupun kelompok, ada beberapa urutan ragam penyajian tari semarangan yang terdiri dari Suka-Suka, Reogan dan GadoGado. Pada bagian Suka-Suka, Oleng, Geyol, Gedeg Seblak. Sedangkan bagian Reogan adalah Reogan, Rongeh, Ngroyong, Laku Papat, Solah, Egol dan pada akhir Reogan adalah Kiyal. Kemudian pada bagian GadoGado terdiri dari Lonthang, Pangkat Ngoyek, Ngoyek, Munjuk, Landai, Merong, Ngirig, Jungkitan, Mandeg, Laku Telu, Nacah, Kicat dan Sorong. (Agus,Alusius,2001: 34).

Penelitian ini bertujuan untuk melihat keefektivan pemakaian modul yang telah dihasilkan dari penelitian 
hibah bersaing dengan judul Pengembangan Model Pelatihan Apresiasi Seni Tari Daerah Setempat pada Guru se-Kota Semarang tahun 2013 yang telah menghasilkan modul dan video tari Denok (Wahyu,2013:5). Mengajak anak untuk ikut terlibat dalam praktek gerak tari akan mengembangkan motorik anak dan merangsang kreatifitas gerak, selain itu penelitian ini sebagai contoh untuk materi selanjutnya dan disarankan kepada Dinas Pendidikan agar lebih memperhatikan dan meningkatkan penggunaan materi seni budaya khususnya seni tari pada gerak tari tradisi sebagai materi pembelajaran tari disekolah (Hartono,Indriyanto, 2013:4)

Sri Ambarwangi, Maman Rachman (2015: 15/1:68) menyatakan Efektif apabila telah tercapainya suatu tujuan dan meningkatan kemampuan guru dalam pelaksanaan pengajaran dikelas.

\section{B. METODE}

Menurut Sugiyono (2008:8) Metode penelitian kuantitatif dapat diartikan sebagai metode penelitan yang berlandaskan pada sample filsafat positivisme, digunakan untuk meneliti pada populasi atau sample tertentu, pengumpulan data menggunakan instrument penelitian, analisis data bersifat kuantitatif /statistic, dengan tujuan untuk menguji hipotesis yang telah ditetapkan. Dengan menggunakan beberapa tekhnik pengumpulan data yaitu, obsevasi, wawancara, tes, kuesioner, dokumentasi, yang kemudian data dianalisis secara deskriptif presentase. Menurut Ruslan (2008:221) metode observasi merupakan metode pengumpulan data yang dilakukan peneliti untuk mencatat dan mengamati suatu peristiwa secara langsung dan peneliti dapat juga sebagai partisipan atau observer. Penelitian kuantitatif dilakukan pada populasi atau sempel yang telah ditentukan. Proses penelitian bersifat deduktik, dimana untuk menjawab rumusan masalah menggunakan konsep atau teori sehingga dapat 
dirumuskan secara hipotesis. Populasi dalam penelitian ini adalah SD Nasima Semarang.). Sampel penelitian ini adalah siswa siswi kelas VI D di SD Nasima Semarang.

instrument pengumpulan data yang digunakan adalah soal pretest, postest dan angket. Soal pretest dan postest digunakan untuk mengetahui keefektifan belajar siswa setelah diterapkan model pelatihan apresiasi seni tari daerah setempat (tari Semarangan) dalam pembelajaran. Angket digunakan memperoleh data yang berkaitan dengan efektivitas model pelatihan apresiasi seni tari daerah setempat. Data dianalisis secara deskriptif persentase. Penelitian ini data kuantitatif yakni data berupa skor penilaian siswa serta skor hasil pretest dan posttest. Analisis data kuantitatif dijelaskan sebagai berikut :

Analisis ini bertujuan untuk mengetahui sejauh mana penerimaan siswa terhadap efektivitas model pelatihan apresiasi seni tari daerah setempat (tari Semarangan) di SD Nasima Semarang. Data kuantitatif skor penilaian angket siswa dianalisis dengan acuan yang diadaptasi dari Akdon dan Riduwan (2007: 87-90) yaitu dengan menggunakan skala Liket yang nantinya akan dideskripsikan secara kualitatif. Skala yang digunakan dalam penelitian pengembangan ini adalah 4 skala yaitu sangat setuju (SS) dengan skor 4, setuju (S) dengan skor 3 , tidak setuju (TS) dengan skor 2, dan sangat tidak setuju (STS) dengan skor

Penilaian tiap butir dianalisis dengan cara :

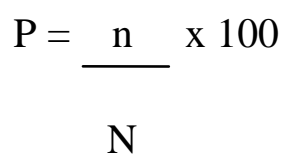

Ket: $\mathrm{P}=$ Presentasi

$$
\begin{aligned}
& \mathrm{n}=\text { jumlah skor yang diperoleh } \\
& \mathrm{N}=\text { jumlah skor total }
\end{aligned}
$$

Skor dalam penilaian dapat tercapai apabila rata-rata penilaian dari tiap indikator angket adalah kategori tinggi. Indikator kategori untuk tiap item indikator angket yaitu dikatakan tinggi ( $\mathrm{T}$ ) jika nilainya $\geq 3$ dan dikatakan dalam kategori rendah (R) jika nilainya $<3$. 
Data skor hasil pretest dan postes dianalisis dengan menghitung nilai dari hasil pretest dan postes. Skor hasil pretes dan postes menunjukan keefektifan model pelatihan apresiasi seni tari daerah setempat (tari Semarangan) yang diterapkan. Indikator keefektifan model pelatihan apresiasi seni tari daerah setempat (tari Semarangan) yang diterapkan dalam penelitian ini yaitu apabila terjadi peningkatan nilai antara hasil pretest (sebelum menerapkan model pelatihan apresiasi seni tari daerah setempat (tari Semarangan)) dengan hasil postes (setelah menerapkan model pelatihan apresiasi seni tari daerah setempat (tari Semarangan))

\section{HASIL PENELITIAN DAN PEMBAHASAN}

Pelajaran SBK kususnya seni tari di SD Nasima sudah berkembang. Tetapi sangat disayangkan bahwa kuranya materi atau bahan ajar (modul) dalam proses pembelajaran sehingga pembelajaran hanya terpaku pada guru SBK saja. Peneliti membantu guru untuk pembuatan modul. Guru sebagai subjek bagi siswa sekaligus objek bagi peneliti. Guru harus menguasai materi yaitu tari Semarangan sebagai bahan materi pembelajaran kelas VI, sebelum materi disampaikan peneliti terlebih dulu melakukan pelatihan materi tari Semarangan kepada guru SBK SD Nasima dan mengamati untuk mengetahui keefektifan metode guru dalam penyampaian sebuah materi kepada siswa. Mata pelajaran seni tari untuk masing-masing kelas dilaksanakan satu kali dalam seminggu. Pembelajaran dibagi 2 karena materi putra dan putrid berbeda. Siswa putra mendapatkan 30 ragam gerak dan putrid mendapatkan 43 ragam gerak. Jumlah pertemuan yang digunakan untuk menyampaikan materi pokok tari Semarangan yaitu 8 kali pertemuan, dengan rincian 2 pertemuan digunakan untuk mengambil data pretest dan postes, 6 pertemuan digunakan untuk pembelajaran tari Semarangan. Pertemuan pertama sebagai pengenalan materi tari Semarangan dengan mengadakan pretest, yang 
dimana untuk mengetahui data nilai siswa. Pertemuan selanjutnya yaitu 6 kali pertemuan siswa mendapatkan materi tari Semarangan dengan metode ceramah dan demonstrasi. Selama proses pembelajaran tari Semarangan guru menjelaskan sejarah, nama ragam, busana, rias dan property yang digunakan serta mengajak siswa kelas VI D untuk dapat berperan aktif dengan melibatkan secara langsung dalam praktek tari Semarangan.

Data hasil belajar siswa sebelum diberikan materi tari Semarangan menunjukan bahwa rata-rata dari jumlah siswa 26 pada kelas VI D adalah 46,15. Rata-rata nilai yang diperoleh belum memenuhi criteria ketuntasan minimal (kkm) yaitu 75 . Nilai tertinggi pada hasil pretest ialah 70, Sedangkan hasil nilai terendah 20. Dengan hasil yang belum memenuhi standar ketuntasan , maka dilakukan upaya peningkatan hasil belajar siswa kelas VI D melalui penerapan model pelatihan apresiasi tari daerah setempat dan materi yang sama yaitu tari
Semarangan untuk dilihat efektifitas pembelajaran apresiasi seni tari.

Setelah siswa kelas VI D SD Nasima diberikan materi tari Semarangan, maka dilakukan postest, yang menunjukan peningkatan hasil perolehan nilai siswa dengan rata-rata sebesar 43,08 dengan nilai tertinggi mendaptkan 100 dan nilai terendah mendapatkan 80 , yang artinya sudah mencapai nilai ketuntasan. Selanjutnya Penyebaran angket sikap siswa ini mempunyai tujuan yaitu untuk mengetahui sejauh mana siswa menerima pembelajaran seni tari yang menerapkan model pembelajaran apresiasi seni tari daerah setempat (tari Semarangan). Angket sikap siswa yang berisikan dua puluh lima indikator berupa pernyataan yang harus diisi oleh siswa dengan rating scale 4, 3, 2, 1. Skor 4 diberikan pada jawaban siswa apabila siswa sangat setuju dengan pernyataan, 3 apa bila siswa setuju dengan pernyataan, 2 apabila siswa tidak setuju, dan 1 apabila siswa sangat tidak setuju. Berdasarkan angket sikap yang 
berisikan 25 butir pernyataan yang menekankan pada beberapa aspek pembelajaran yang menilai guru dan siswa, yang dimana dapat mengetahui respon siswa. Aspek-aspek yang dinilai dalam angket sikap adalah kesiapan siswa sebelum pembelajaran dimulai, kedisiplinan siswa dan guru, ketertarikan dan keseriusan siswa dalam pembelajaran seni tari, properti yang digunakan, metode guru saat mengajar, media mengajar guru. Proses pembelajaran apresiasi tari Semarangan di SD Nasima berlangsung sangat baik. Hal ini dapat dilihat pada tabel analisis sikap kelas VI D yang tergolong tinggi yaitu dengan perolehan rata-rata nilai siswa lebih dari 3.

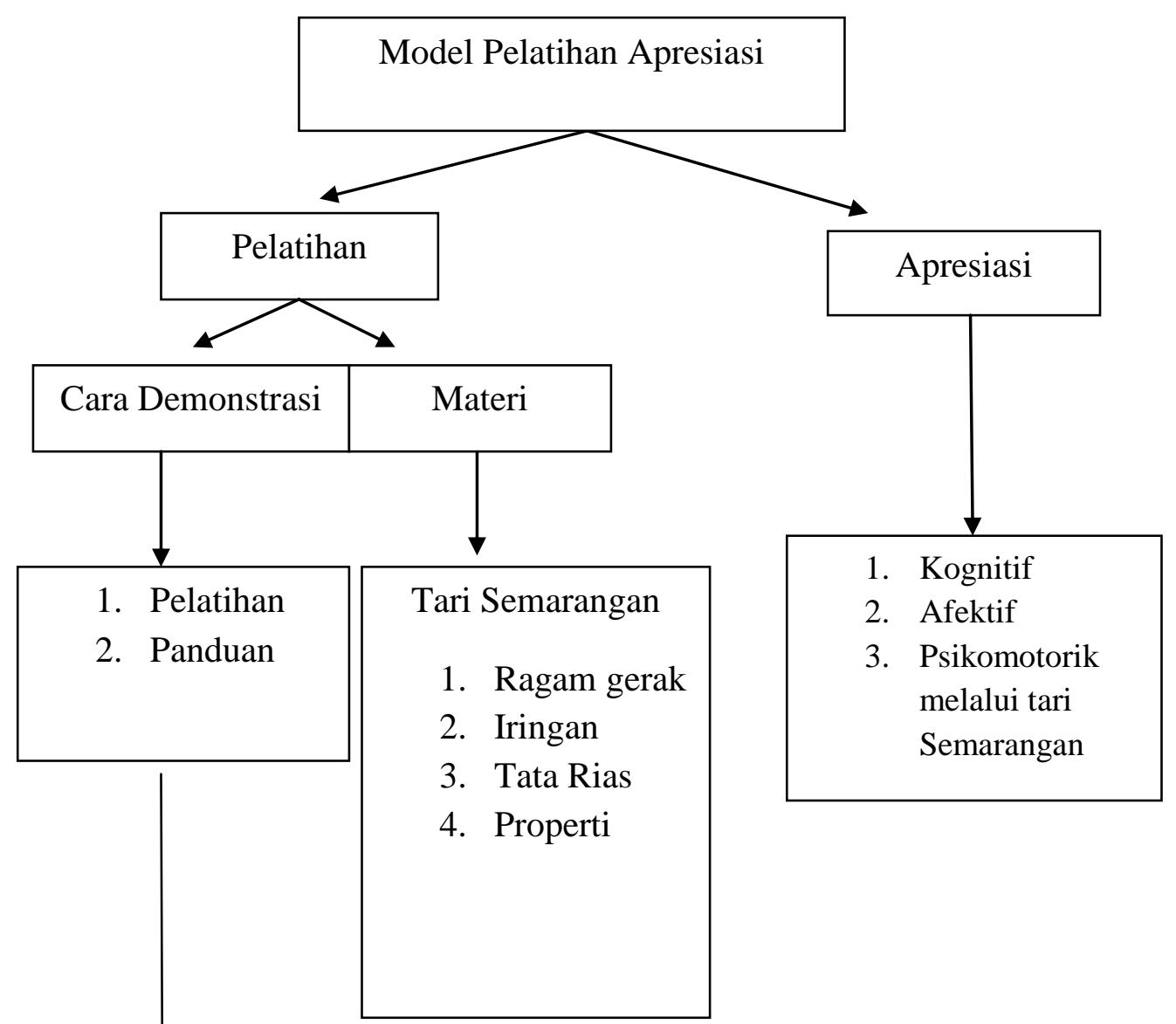




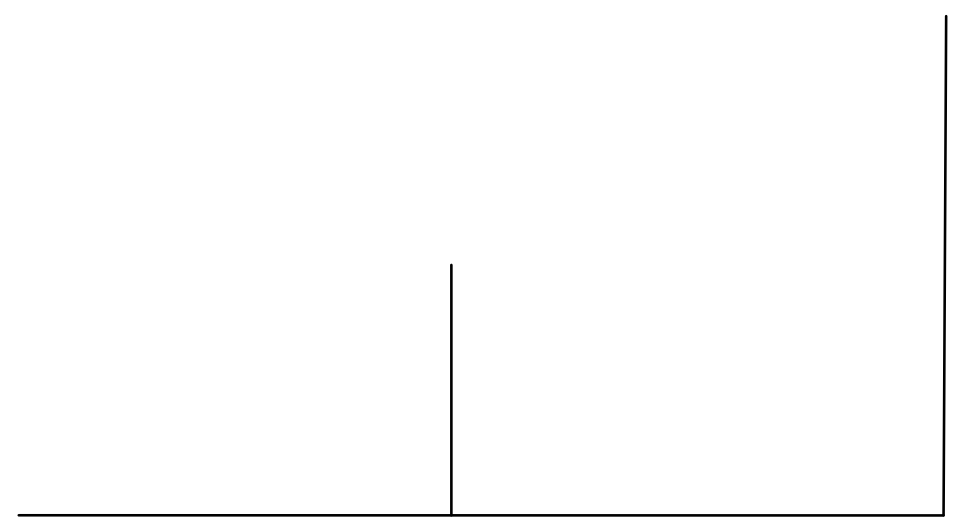

Pada aspek psikomotorik terdiri dari tiga indikator sebagai pedoman penilaian, yaitu hafalan gerak, kesesuaian iringan, dan ekspresi siswa saat menarikan tari Semarangan. Pemberian nilai psikomotorik berdasarkan pada rating scale 5, 4, 3, 2,1 , dengan bobot skor yang berbeda pula. Skor 5 diberikan apabila siswa hafal semua gerakan tari Semarangan dari awal hingga akhir dengan rentan nilai 21-25. Skor 4 apabila siswa hafal gerak tari Semarangan lebih dari $75 \%$ ragam gerak dengan rentan nilai 16 20. Skor 3 apabila siswa hafal gerak tari Semarangan lebih dari 50\% ragam gerak dengan rentang nilai $11-15$. Skor 2 apabila siswa hafal gerak tari Semarangan lebih dari 25\% ragam gerak dengan rentan nilai $6-10$, sedangkan skor 1 apabila siswa hafal gerak tari Semarangan kurang dari $25 \%$ ragam gerak dengan rentang nilai 1 - 5. Begitu jumlah skor maksimal dalam lembar penilaian aspek psikomotorik adalah 75. Dapat 
diketahui hasil penilaian psikomotorik siswa dimana 14 siswa dikategorikan mendapat nilai baik dengan rata-rata nilai 81-85, 8 siswa dikategorikan nilai cukup dengan rata-rata 75 dan 5 siswa mendapatkan nilai dengan kategori sangat baik yang rata-rata diatas 85 . Nilai psikomotorik siswa didapat dengan cara menghitung jumlah skor yang diperoleh siswa dibagi dengan jumlah skor maksimal dan dikalikan 100.

\section{SIMPULAN}

Dapat disimpulkan bahwa model pelatihan apresiasi seni tari daerah setempat (tari Semarangan) efektif untuk pembelajaran seni tari pada siswa sekolah dasar dengan materi tari Semarangan. Keefekvititasan model pelatihan apresiasi seni tari daerah setempat (tari Semarangan) di SD Nasima Semarang ditunjukan dengan (1) Meningkatnya hasil belajar kognitif siswa materi pokok tari Semarangan dengan model pelatihan apresiasi seni tari daerah setempat (tari Semarangan) di SD Nasima sebesar 43,08. (2) Hasil nilai psikomotorik siswa pada tari
Semarangan kelas VI D di SD Nasima sudah diatas batas nilai ketuntasan dengan rata-rata 83,3 yang termasuk dalam kategori baik (4) Antusias siswa terhadap penerapan model pelatihan apresiasi seni tari daerah setempat (tari Semarangan) di SD Nasima tinggi dengan mayoritas siswa memberikan respon positif terhadap pembelajaran yaitu sebesar 3,19 (tinggi) dan 65\% dari jumlah siswa kelas VI D di SD Nasima menyukai pelajaran seni tari.

\section{Daftar Pustaka}

Agus, Alusius. 2001. Analisis Struktur Tari Semarangan. Skripsi. Tidak Dipublikasikan

Amabarwati, Sri dan Maman Rachman. 2015. Holistic Academic Supervision Model For Cultural Art Teacher Of Vocational High School. Journal Harmonia. 15/1: 68

Akdon dan Riduwan. 2007. Rumus dan Data Analisis Statistika. Bandung: Alfabeta.

Hartono. 2012. Pembelajaran Tari Anak Usia Dini. Semarang: Unnes Press. 
Jazuli. 2008, Paradigma Kontekstual Pendidikan Seni. UNNES Press

Joko, 2010. Perbedaan Pengaruh Metode Latihan Massed Practice dan Distributed Practice Terhadap Hasil Shooting Bola Basket Pada Siswa Ekstrakulikuler Bola Basket SMK Negeri 2 Surakarta Tahun Pelajaran 2010/2011. Skripsi. Tidak Dipublikasikan.

Latifatul, Mida. 2013. Kupas Tuntas Kurikulum 2013. Semarang. Kata Pena

Lestari, Wahyu dan Totok Sumaryanto F. 2014. Pengembangan Model Pelatihan Apresiasi Seni Tari Daerah Setempat Pada Guru Sekolah dasar di Kota Semarang. Semarang: UNNES,

Lestari, Wahyu dan Hartono, Indriyanto. 2013. Model Pembelajaran seni (Tari) Untuk Anak TK berbasis seni tradisi dan penguatan karakte. Unduhan google 12/8/2015, 8:53PM

Ruslan, Rosady. 2008. Metode Penelitian Public Relations dan Komunikasi. Jakarta: Raja grafindo Persada

Sugiyono. 2008. Metode Penelitian Kuantitatif, Kualitatif dan $R \& D$. Bandung: Alfabeta

Purnaningtyas, A., \& Suharto, S. (2011). PENGARUH KECERDASAN EMOSI TERHADAP PRESTASI BELAJAR SISWA MATA PELAJARAN SENI BUDAYA SMP. Harmonia: Journal Of Arts Research And Education, 10(1). doi:http://dx.doi.org/10.15294 /harmonia.v10i1.56

Suharto, S. (2011). Refleksi Teori Kritik Seni Holistik : sebuah Pendekatan Alternatif dalam Penelitian Kualitatif bagi Mahasiswa Seni (Reflection on Art Criticism and Holistic Art Criticism : an Alternative Approach of Qualitative Research for Art Students). Harmonia: Journal Of Arts Research And Education, 8(1).

doi:http://dx.doi.org/10.15294 /harmonia.v8i1.803

Malarsih, M., \& Herlinah, H. (2014). Creativity Education Model through Dance Creation for Students of Junior High School. Harmonia: Journal Of 
Arts Research And Education, 14(2), 147-157.

doi:http://dx.doi.org/10.15294

/harmonia.v14i2.3296 